\title{
A simple method for the genetic identification of commercially important species in the Opisthonema genus Gill, 1861 in the southern Gulf of California
}

\section{Un método sencillo para la identificación genética de especies comercialmente importantes del género Opisthonema Gill, 1861 en el sur del golfo de California}

\author{
Carlos Iván Pérez-Quiñonez, Casimiro Quiñonez-Velázquez, Francisco Javier García-Rodríguez* \\ Instituto Politécnico Nacional-Centro Interdisciplinario de Ciencias Marinas, Playa El Conchalito, s/n, Apdo. \\ Postal 592, CP 23000, La Paz, Baja California Sur, Mexico. \\ * Corresponding author. E-mail: fjgarciar@ipn.mx
}

\begin{abstract}
The polymerase chain reaction-restriction fragment length polymorphism (PCR-RFLP) technique was used to identify 3 species in the genus Opisthonema (Opisthonema bulleri, Opisthonema medirastre, and Opisthonema libertate) in the southern Gulf of California. Two specific primer pairs were designed to amplify the COI mitochondrial gene and 3 restriction enzymes (HpaII, RsaI, and AvaII) were selected to compare the RFLP patterns among the species. Different polymorphism levels were detected among samples. Easily analyzed specific restriction profiles were created, which differentiated unequivocally among the 3 target species. The approach undertaken here using PCR-RFLP is relatively cheap, fast, and robust, providing a useful technique for the identification of species in the genus Opisthonema.
\end{abstract}

Key words: PCR-RFLP, Opisthonema, restriction enzymes, COI gene, identification.

RESUMEN. Se aplicó la técnica de reacción en cadena de la polimerasa-polimorfismos de longitud de fragmentos de restricción (PCR-RFLP, por sus siglas en inglés) para identificar 3 especies del género Opisthonema (Opisthonema bulleri, Opisthonema medirastre y Opisthonema libertate) en la región sur del golfo de California. Se diseñaron 2 pares de iniciadores específicos para amplificar el gen mitocondrial COI y se seleccionaron 3 enzimas de restricción (HpaII, RsaI y AvaII) para comparar los patrones de RFLP entre las especies. Diferentes niveles de polimorfismo fueron detectados entre las muestras. Se generaron perfiles de restricción específicos fáciles de analizar, los cuales pudieran distinguir de manera inequívoca las 3 especies objetivo. El enfoque llevado a cabo aquí usando PCR-RFLP es relativamente barato, rápido y robusto, y proporciona una técnica útil para la identificación de las especies del género Opisthonema.

Palabras clave: PCR-RFLP, Opisthonema, enzimas de restricción, gen COI, identificación.

\section{INTRODUCTION}

Three Pacific thread herring species comprise a fishery resource of great commercial importance along the Pacific coast of eastern Mexico, namely, Opisthonema bulleri (Regan, 1904), Opisthonema medirastre (Berry and Barrett, 1963), and Opisthonema libertate (Günther, 1867). Their distribution extends from the western coast of the Baja California Peninsula and the Gulf of California to northern Peru (Berry and Barrett 1963).

Fisheries statistics in Mexico do not report catches by species, as identification based on morphological characteristics is difficult, and catches are therefore recorded as Pacific thread herring (Opisthonema spp.) (Jacob-Cervantes 2010). The detection of the diagnostic characteristics of these species is thus a relevant endeavor. Berry and Barrett (1963) were the first to propose a methodology for the identification of these species using the number of gill rakers on the ceratobranchial bone of the first gill arch. Torres-Ramírez (2004) proposed the use of gill raker characteristics such as the base and spicules. However, these characteristics can overlap between species, leading to errors in identification. Recently,

\section{INTRODUCCIÓN}

Tres especies de sardina crinuda comprenden un recurso pesquero de gran importancia comercial en la costa mexicana del Pacífico oriental, específicamente, Opisthonema bulleri (Regan, 1904), Opisthonema medirastre (Berry y Barrett, 1963) y Opisthonema libertate (Günther, 1867). Su distribución abarca desde la costa occidental de la península de Baja California y el golfo de California hasta el norte de Perú (Berry y Barrett 1963).

Las estadísticas de pesca en México no reportan las capturas por especie, ya que la identificación basada en características morfológicas es difícil, y, por lo tanto, las capturas se registran como sardina crinuda (Opisthonema spp.) (Jacob-Cervantes 2010). La detección de características diagnósticas de estas especies requiere, por lo tanto, un esfuerzo relevante. Berry y Barrett (1963) fueron los primeros en proponer una metodología para la identificación de estas especies utilizando el número de branquiespinas presentes en el hueso ceratobranquial del primer arco branquial. Torres-Ramírez (2004) propuso el uso de las características de las branquiespinas, relacionadas con la base y las 
Pérez-Quiñónez et al. (2017) used a geometric morphometric analysis and mitochondrial DNA cytochrome oxidase subunit I (COI) gene sequences to describe the particular characteristics of each Pacific thread herring species; this study validated for the first time the existence of the 3 taxonomic entities using genetic data.

Genetic techniques are very useful when morphological information alone does not provide sufficient diagnostic characteristics for species identification or when only part of the organism is recovered (García-Rodríguez et al. 2008, Lampa et al. 2015, Pérez-Quiñónez et al. 2017). The genetic information used for exact identification becomes relevant when commercially important species are evaluated or when it is necessary to verify the authenticity of species that are sold as seafood, avoiding illegal practices that replace cheap species for expensive ones (Alacs et al. 2009, Pérez-Enríquez et al. 2016).

The polymerase chain reaction-restriction fragment length polymorphism (PCR-RFLP) method allows the identification of species based on products created by DNA digestion using restriction enzymes (Guan et al. 2018). This method has the advantage of being fast, simple, robust, and relatively cheaper than the sequencing method, and it has been applied for different purposes, for example, for the identification of organisms in the larval stage or for seafood traceability (García-Rodríguez et al. 2008, Ferrito et al. 2019). Recently, PCR-RFLP procedures have been incorporated into new approaches for detecting aquatic species based on environmental DNA (Clusa et al. 2017, FernándezFernández 2018).

In this study, we report a protocol based on the PCRRFLP technique and on the COI gene for identifying the Pacific thread herring species (Opisthonema spp.) found off the northwestern coast of Mexico. The aim was to provide a quick, effective, and cheap tool to contribute to a better evaluation of this fishery resource that has great relevance in Mexico.

\section{MATERIALS AND METHODS}

\section{Sampling and DNA extraction}

The specimens used in this study were collected in June 2015 in Mazatlán (Sinaloa, Mexico) from landings made by the small pelagic fleet operating from northern Sinaloa to northern Jalisco (Fig. 1, Table 1). All fishes measured $\geq 120 \mathrm{~mm}$ standard length and were taken for adults considering the relationship between length and sexual maturity (Berry and Barrett 1963, Pérez-Quiñónez et al. 2017). To reduce DNA degradation, specimens were collected from the small pelagic fleet as soon as the ships arrived at the harbor. Muscle tissue samples were then obtained and preserved in $95 \%$ ethanol. Specimens were initially identified using the works by Berry and Barret (1963), Torres-Ramírez (2004), and Pérez-Quiñónez et al. (2017). espículas. Sin embargo, estas características pueden traslaparse entre las especies, lo que lleva a errores en la identificación. Recientemente, Pérez-Quiñónez et al. (2017) emplearon análisis de morfometría geométrica y secuencias del gen de la subunidad I del citocromo oxidasa (COI) del ADN mitocondrial para describir las características particulares de cada especie de sardina crinuda; este estudio validó por primera vez la existencia de las 3 entidades taxonómicas con base en datos genéticos.

Los métodos genéticos son muy útiles cuando la información morfológica por sí sola no proporciona suficientes características diagnósticas para la identificación de especies o cuando solo se recupera parte del organismo (García-Rodríguez et al. 2008, Lampa et al. 2015, Pérez-Quiñónez et al. 2017). La información genética utilizada para la identificación exacta es relevante cuando se evalúan especies comercialmente importantes o cuando es necesario verificar la autenticidad de las especies vendidas como alimento marino, lo cual evita prácticas ilegales que reemplacen especies de bajo costo por especies caras (Alacs et al. 2009, Pérez -Enríquez et al. 2016).

El método de reacción en cadena de la polimerasapolimorfismos de longitud de fragmentos de restricción (PCR-RFLP, por sus siglas en inglés) permite la identificación de especies basada en los productos de la digestión del ADN mediante el empleo de enzimas de restricción (Guan et al. 2018). Este método tiene la ventaja de ser rápido, sencillo, robusto y relativamente más barato que la secuenciación, y ha sido aplicado para diferentes propósitos, por ejemplo, para la identificación de organismos en estado larval o para la trazabilidad de alimentos marinos (García-Rodríguez et al. 2008, Ferrito et al. 2019). Recientemente, los procedimientos de PCR-RFLP se han incorporado a nuevos enfoques para detectar especies acuáticas basadas en el ADN ambiental (Clusa et al. 2017, Fernández-Fernández 2018).

En este estudio, se presenta un protocolo basado en la técnica de PCR-RFLP y en el gen COI para la identificación de especies de sardina crinuda (Opisthonema spp.) presentes en la costa noroeste de México. El objetivo fue proporcionar una herramienta rápida, efectiva y barata para contribuir a una mejor evaluación de este recurso pesquero que es de gran relevancia en México.

\section{MATERIALES Y MÉTODOS}

\section{Muestreo y extracción del ADN}

Las muestras utilizadas en este estudio fueron recolectadas en junio de 2015 en Mazatlán (Sinaloa, México) de los desembarques de la flota pesquera de pelágicos menores que opera del norte de Sinaloa al norte de Jalisco (Fig. 1, Tabla 1). Todos los peces presentaron tallas $\geq 120 \mathrm{~mm}$ de longitud estándar y fueron considerados adultos con base en la relación de la talla y la madurez sexual (Berry y Barrett 1963, Pérez-Quiñónez et al. 2017). Para reducir la degradación del 


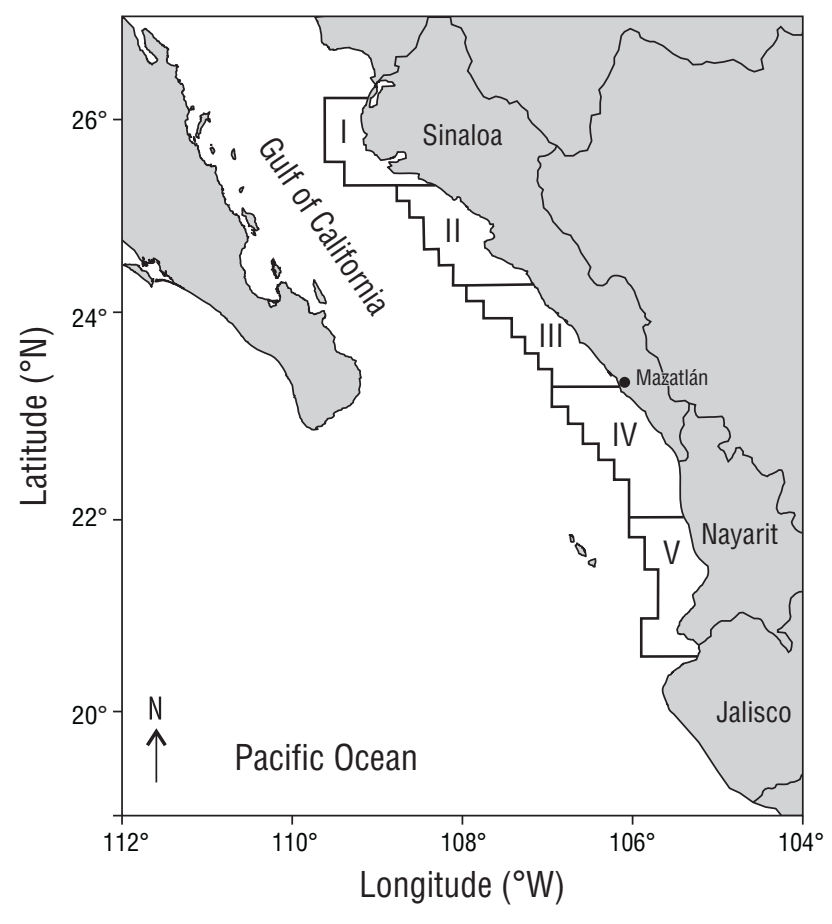

Figure 1. Operation zones used by the small pelagic fishing fleet in the southern Gulf of California, Mexico (I-V).

Figura 1. Zonas administrativas de la flota pesquera de pelágicos menores en el sur del golfo de California, México (I-V).

\section{PCR-RFLP analysis}

The DNA of 18 individuals was obtained using a commercial kit (Qiagen; Hilden Germany). A $~ 464$ bp fragment of COI was amplified using primers COI Olib F (5'CGAGCAGAATTAAGCCAACC) and COI Olib R (5'GGGGTCGAAGAAAGTCGTATT). These primers were designed for this study on the basis of an O. bulleri sequence deposited in GenBank (access number KU587814-KU587838), using the program Primer3 (SDBSWeb: http://bioinfo.ut.ee/primer30.4.0/, accessed 20 January 2017; Koressaar and Remm 2007, Untergasser et al. 2012). PCR was performed in a total volume of $25 \mu \mathrm{L}: 1 \mu \mathrm{L}$ of DNA template, 1X PCR buffer (Invitrogen), $0.2 \mathrm{mM} \mathrm{dNTP}$ mix, $0.24 \mu \mathrm{M}$ of each primer, $2.0 \mathrm{mM} \mathrm{MgCl}_{2}$, and $0.025 \mathrm{U} / \mu \mathrm{L}$ Taq DNA polymerase (Invitrogen). A BioRAd T100 Thermal Cycler was used for the PCR; this consisted in 2 min initial denaturation at $94^{\circ} \mathrm{C}$ and 35 cycles of $30 \mathrm{~s}$ at $94{ }^{\circ} \mathrm{C}$ for denaturation, $30 \mathrm{~s}$ at $49^{\circ} \mathrm{C}$ for annealing, and $1 \mathrm{~min}$ at $72{ }^{\circ} \mathrm{C}$ for extension. A final extension of $10 \mathrm{~min}$ at $72{ }^{\circ} \mathrm{C}$ was performed. Amplifications were verified by electrophoresis in stained $1 \%$ agarose gel and visualized with a UV transilluminator. The gel was stained with GelRed.

Amplified products were sequenced (Macrogen; Seoul, South Korea) in both directions with the same primers used in the amplification. Sequences were edited in the program ChromasPro 1.7.6 (Technelysium Pty. Ltd.) and alignment
Table 1. Sample size. The Seq1-COI column refers to the number of sequences that were amplified and digested in this study. The RFLP-COI column refers to the number of sequences obtained from Genbank to evaluate the consistency of the restriction patterns.

Tabla 1. Tamaño de muestra. La columna Seq1-COI se refiere al número de secuencias amplificadas y digeridas en este estudio. La columna RFLP-COI se refiere al número de secuencias obtenidas de Genbank para evaluar la consistencia de los patrones de restricción.

\begin{tabular}{lccc}
\hline Species & Seq1-COI & RFLP-COI & Total \\
\hline Opisthonema bulleri & 6 & 8 & 14 \\
Opisthonema medirastre & 6 & 10 & 16 \\
Opisthonema libertate & 6 & 7 & 13 \\
Total & 18 & 25 & 43 \\
\hline
\end{tabular}

$\mathrm{ADN}$, los individuos fueron obtenidos tan pronto como los barcos llegaron al puerto. Luego, se obtuvieron muestras de tejido muscular y se conservaron en etanol al 95\%. Los especímenes se identificaron en un principio usando los trabajos de Berry y Barret (1963), Torres-Ramírez (2004) y Pérez-Quiñónez et al. (2017).

\section{Análisis de PCR-RFLP}

El ADN total de 18 individuos se obtuvo con un kit comercial (Qiagen; Hilden, Alemania). Se amplificó un fragmento de $\sim 464 \mathrm{pb}$ del gen COI utilizando los iniciadores COI Olib F (5'CGAGCAGAATTAAGCCAACC) y COI Olib R (5'GGGGTCGAAGAAAGTCGTATT). Estos iniciadores fueron diseñados para este estudio con base en una secuencia de $O$. bulleri depositada en GenBank (número de acceso KU587814-KU587838) utilizando el programa Primer3 (SDBSWeb: http://bioinfo.ut.ee/primer3-0.4.0/, accedido 20 de enero de 2017; Koressaar y Remm 2007, Untergasser et al. 2012). La PCR se realizó en un volumen total de $25 \mu \mathrm{L}: 1 \mu \mathrm{L}$ de ADN, 1X de tampón para PCR (Invitrogen), $0.2 \mathrm{mM}$ de mezcla de dNTP, $0.24 \mu \mathrm{M}$ de cada primer, $2.0 \mathrm{mM}$ de $\mathrm{MgCl}_{2}$ y $0.025 \mathrm{U} / \mu \mathrm{L}$ de ADN Taq polimerasa (Invitrogen). Se utilizó un termociclador BioRAd T100 para la PCR, la cual consistió en 2 min de desnaturalización inicial a $94{ }^{\circ} \mathrm{C}$ y 35 ciclos de $30 \mathrm{~s}$ a $94{ }^{\circ} \mathrm{C}$ para la desnaturalización, $30 \mathrm{~s} \mathrm{a}$ $49^{\circ} \mathrm{C}$ para el alineamiento y 1 min a $72{ }^{\circ} \mathrm{C}$ para la extensión. Se realizó una extensión final de $10 \mathrm{~min}$ a $72{ }^{\circ} \mathrm{C}$. Las amplificaciones se verificaron por electroforesis en gel de agarosa al $1 \%$ y se visualizaron con un transiluminador de UV. El gel se tiñó con GelRed.

Los productos amplificados se secuenciaron (Macrogen; Seúl, Corea del Sur) en ambas direcciones con los mismos iniciadores utilizados en la amplificación. Las secuencias se editaron en el programa ChromasPro 1.7.6 (Technelysium Pty. Ltd.) y el alineamiento se realizó utilizando el algoritmo Clustal W (Thompson et al. 1997) incorporado en el programa Mega 6 (Tamura et al. 2013). Las secuencias se depositaron en GenBank (número de acceso MN745299-MN745316). Se 
was performed using Clustal W (Thompson et al. 1997) in Mega 6 (Tamura et al. 2013). Sequences were deposited in GenBank (accession number MN745299-MN745316). Three sequences (one for each species) were used for the identification of diagnostic restriction enzyme recognition sites in ChromasPro software v.1.7.6 (Technelysium Pty. Ltd.). Even though several restriction enzymes revealed various cut sites in the sequences, we selected only those that digested fragments that could easily be seen on agarose gel and presented no more than 3 cut sites. To visualize the RFLP pattern, the 18 amplified products were digested using a final $7.0 \mu \mathrm{L}$ volume with 0.7 unit $/ \mu \mathrm{L}$ of the selected enzyme and $3.5 \mu \mathrm{L}$ PCR product, considering the manufacturer's instructions (New England Biolabs; Ipswich, MA). The digestion was directly done of unpurified PCR products, as has been done in other studies (Lin and Hwang 2007, García-Rodríguez et al. 2008, Vergara-Chen et al. 2009, Guan et al. 2018). Reaction products for each enzyme were incubated for $20 \mathrm{~min}$ at the optimal temperature suggested by the manufacturer. For electrophoresis, restricted products were run on $1.5 \%$ agarose gel and stained with GelRed. A molecular weight marker was added to the agarose gel to estimate fragment size. The consistency of the restriction sites was reviewed by increasing the number of sequences to 43 (Table 1): 18 sequences amplified in this study plus the 25 sequences downloaded from Genbank (access number KU587814-KU587838).

\section{RESULTS}

The COI gene fragment was correctly amplified for the 3 Pacific thread herring species, with an estimated size of 464 bp. Three restriction enzymes (HpaII, CCGG; AvaII, GGWCC; and RsaI, GTAC) were selected, as they allowed discrimination between the 3 species. Figure 2 shows the restriction sites for the 18 sequences that were amplified and digested in this study. The HpaII enzyme recognized 1 restriction site for $O$. libertate to generate 2 fragments (haplotype A), 3 and 2 restriction sites for $O$. medirastre to generate 4 and 3 fragments (haplotype $\mathrm{B}$ and haplotype $\mathrm{C}$, respectively), and no restriction sites for $O$. bulleri (haplotype D). The AvaII enzyme did not recognize restriction sites for O. medirastre or O. libertate (haplotype A) and recognized only 1 restriction site for $O$. bulleri to generate 2 fragments (haplotype B). Finally, the enzyme RsaI recognized one restriction site for $O$. libertate and $O$. bulleri to generate 2 fragments (haplotype A) and no restriction sites for O. medirastre (haplotype B). All electrophoretic patterns obtained from the PCR-RFLP products were congruent with expected results based on sequence analysis (Fig. 3).

The consistency of the restriction patterns considering also the 25 sequences downloaded from Genbank was high in the 3 species with the HpaII and AvaII enzymes, since no new haplotype was found. However, the RsaI enzyme presented additional restriction patterns for $O$. libertate, characterized utilizaron 3 secuencias (una de cada especie) para la identificación de sitios de reconocimiento diagnóstico de enzimas de restricción en el software ChromasPro v.1.7.6 (Technelysium Pty. Ltd.). Aunque varias enzimas de restricción revelaron varios sitios de corte en las secuencias, se seleccionaron sólo aquellas que digirieron fragmentos que podían ser fácilmente visibles en el gel de agarosa y que no presentaron más de 3 sitios de corte. Para visualizar el patrón RFLP, los 18 productos amplificados se digirieron usando un volumen final de $7.0 \mu \mathrm{L}$ con 0.7 unidades $/ \mu \mathrm{L}$ de la enzima seleccionada y $3.5 \mu \mathrm{L}$ de producto de la PCR, siguiendo las instrucciones del fabricante (New England Biolabs; Ipswich, MA). La digestión se realizó directamente de los productos de la PCR no purificados, como se ha realizado en otros estudios (Lin y Hwang 2007, García-Rodríguez et al. 2008, VergaraChen et al. 2009, Guan et al. 2018). Los productos de reacción para cada enzima se incubaron durante $20 \mathrm{~min}$ a la temperatura óptima sugerida por el fabricante. Para la electroforesis, los productos restringidos se procesaron en un gel de agarosa al $1.5 \%$ y se tiñeron con GelRed. Se añadió un marcador de peso molecular al gel de agarosa para estimar el tamaño del fragmento. Se revisó la consistencia de los sitios de restricción aumentando el número de secuencias a 43 (Tabla 1): 18 secuencias amplificadas en este estudio más 25 secuencias descargadas de Genbank (número de acceso KU587814-KU587838).

\section{RESUltados}

El fragmento del gen COI se amplificó correctamente para las 3 especies de sardina crinuda, con un tamaño estimado de $464 \mathrm{pb}$. Se seleccionaron 3 enzimas de restricción (HpaII, CCGG; AvaII, GGWCC; y RsaI, GTAC) debido a que permitieron la discriminación de las 3 especies. La Figura 2 muestra los sitios de restricción de las 18 secuencias amplificadas y digeridas en este estudio. La enzima HpaII reconoció 1 sitio de restricción en $O$. libertate para generar 2 fragmentos (haplotipo A), 3 y 2 sitios de restricción en $O$. medirastre para generar 4 y 3 fragmentos (haplotipo B y haplotipo C, respectivamente) y ningún sitio de restricción en $O$. bulleri (haplotipo D). La enzima AvaII no reconoció ningún sitio de restricción en O. medirastre y en O. libertate (haplotipo A) y sólo reconoció 1 sitio de restricción en $O$. bulleri para generar 2 fragmentos (haplotipo B). Finalmente, la enzima $R s a \mathrm{I}$ reconoció un sitio de restricción en O. libertate y en O. bulleri para generar 2 fragmentos (haplotipo A) y ningún sitio de restricción en $O$. medirastre (haplotipo B). Todos los patrones electroforéticos obtenidos de los productos de PCR-RFLP fueron congruentes con los resultados esperados basados en el análisis de secuencia (Fig. 3).

La consistencia de los patrones de restricción considerando también las 25 secuencias descargadas de Genbank fue alta en las 3 especies con las enzimas HpaII y AvaII, ya que no se encontró ningún haplotipo nuevo. Sin embargo, la enzima RsaI presentó patrones de restricción adicionales 
Pérez-Quiñones et al.: Genetic identification of species in the Opisthonema genus

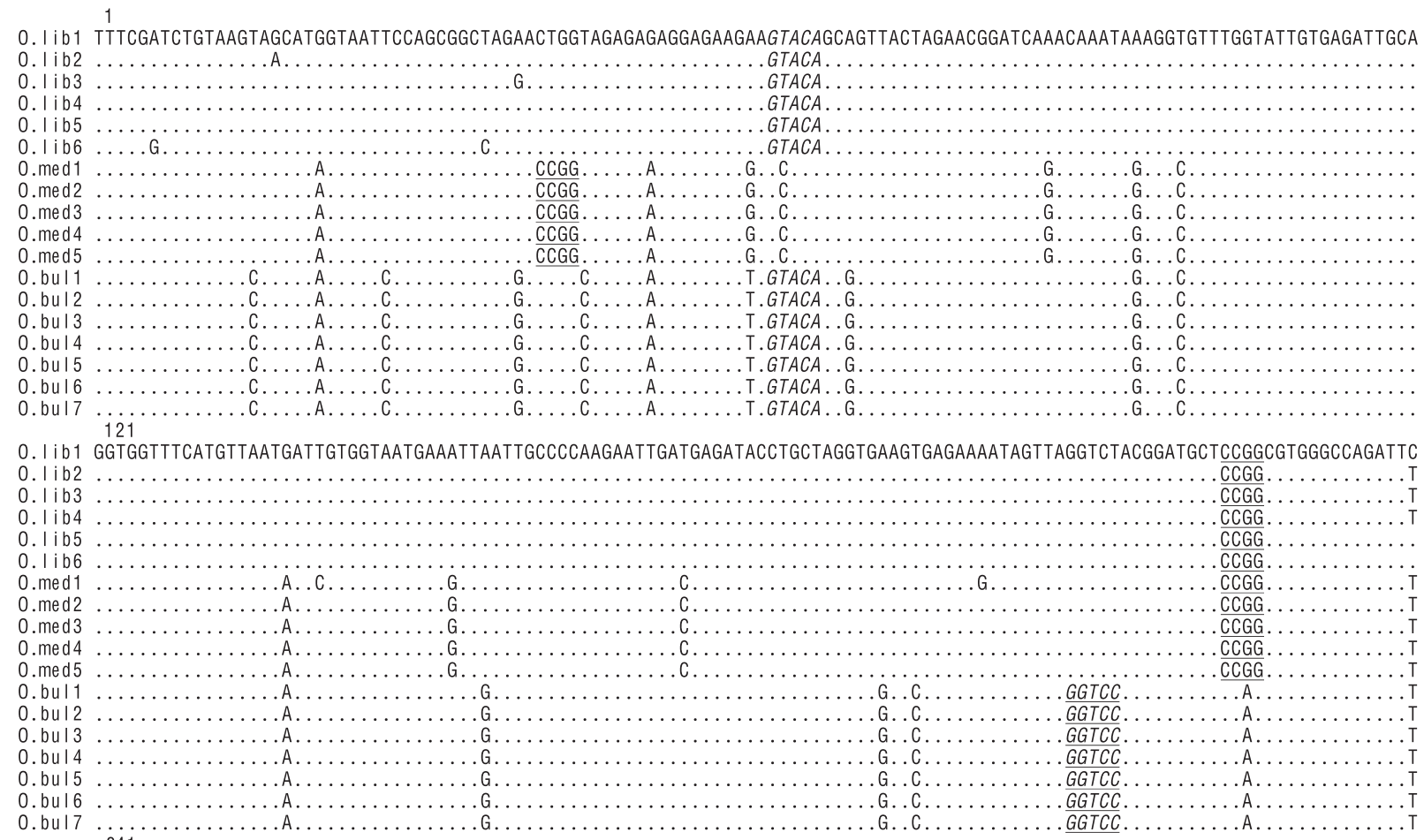

$0 . \mathrm{bul}$

24

(G...

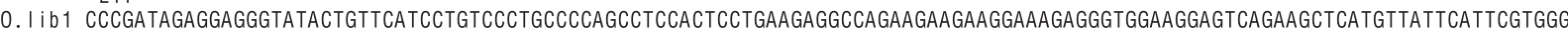

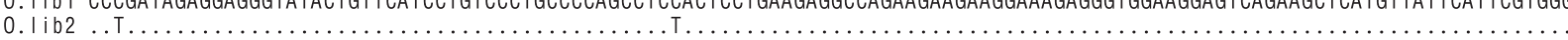

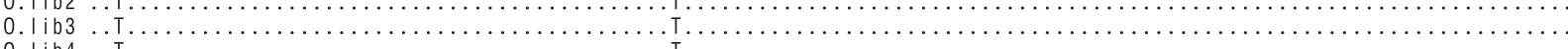

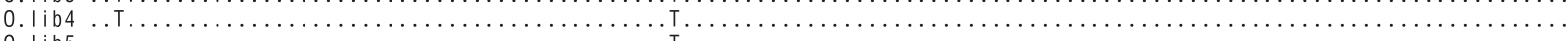

0.1 ib5

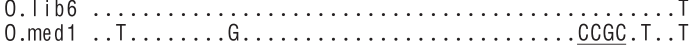

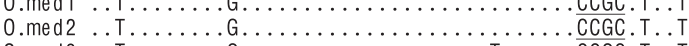

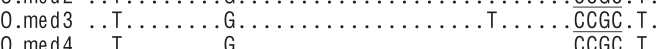

$0 . \operatorname{med} 4$

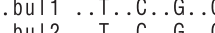

D.bul3 ..T..C..G..G.

O.bul4 ..T.....G...

O.bul5 . .T.....G.G.

0. bul7 .T.C...G.G.

0.l ib1 AATGCCATATCTGGTGCTCCGATCATTAAAGGAACGAGCCAGTTTCCAAATCCTCCGATCAGGATTGGCATTACTATGAAGAAAATCATTACGAAGGCATGCGC

0.1 ib2

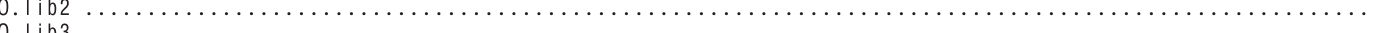

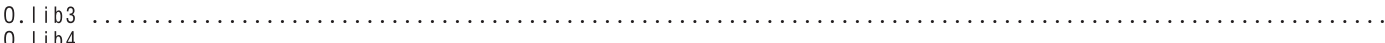

0.1 ib 4

0.1 ib 5

$0.1 \mathrm{ib} 6$

$0 . \operatorname{med} 2$.

O.med 3

$0 . \operatorname{med} 4$

0.med 5

0 .bul

$0 . \mathrm{bul}$

0. bul3

0. bul 4

0. bul5

$0 . \mathrm{bul} 6$

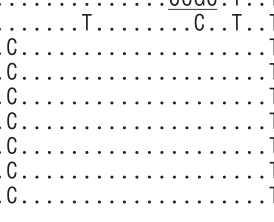

(c)

(n.
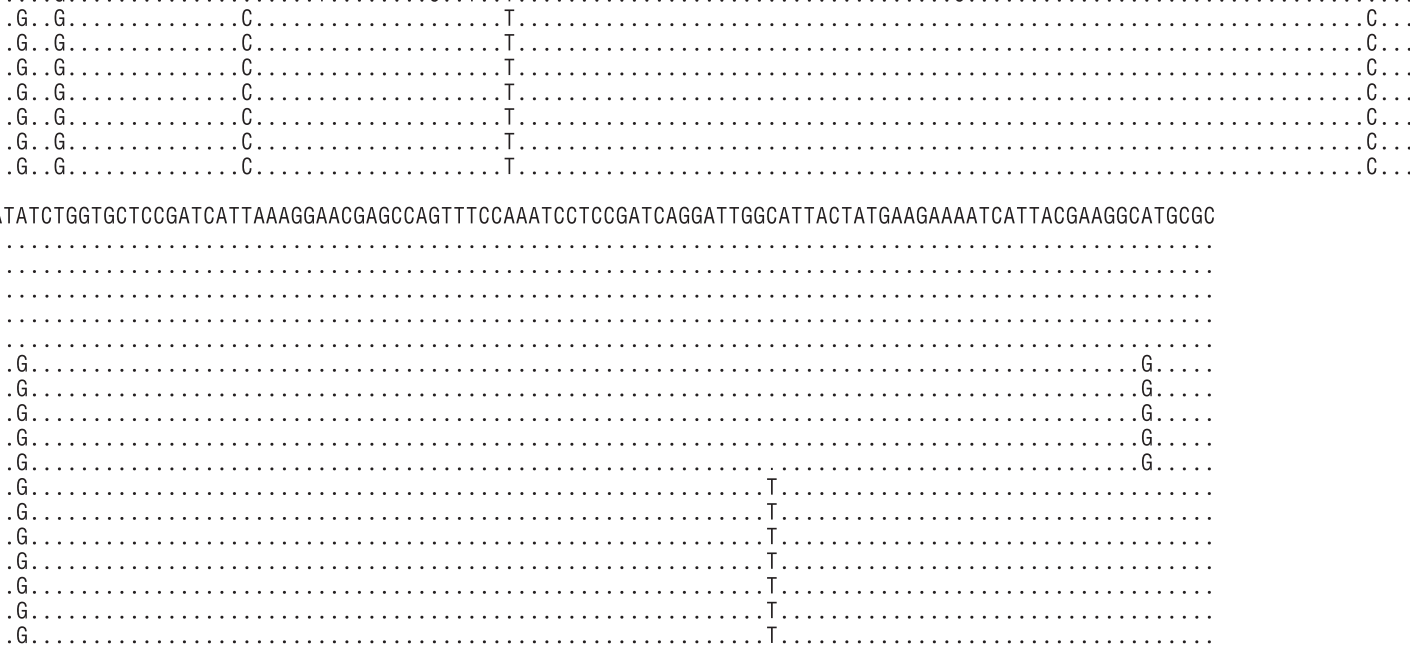

Figure 2. Nucleotide variations within and among species as obtained from the alignment of the 18 nucleotide sequences of the Pacific thread herring COI mitochondrial gene: Opisthonema bulleri (O.bul), Opisthonema libertate (O.lib), and Opisthonema medirastre (O.med). HpaII, RsaI, and AvaII recognition sites are underlined, italicized, and underlined/italicized, respectively. Dots indicate the same nucleotide as the O.lib1 sequence samples. The tag after the species abbreviation indicates the specimen code. Numbers 1, 121, 241, and 361 indicate the positions in the sequence of the first nucleotide in the row.

Figura 2. Variaciones de nucleótidos dentro y entre especies como resultado de la alineación de 18 secuencias de nucleótidos del gen mitocondrial COI de sardina crinuda: Opisthonema bulleri (O.bul), Opisthonema libertate (O.lib) y Opisthonema medirastre (O.med). Los sitios de reconocimiento de HpaII, RsaI y AvaII están subrayados, en cursiva, y subrayados y en cursiva, respectivamente. Los puntos indican el mismo nucleótido que las muestras de la secuencia O.lib1. La etiqueta después del nombre abreviado de la especie indica el código del espécimen. Los números 1, 121, 241 y 361 indican las posiciones en la secuencia del primer nucleótido en la fila. 

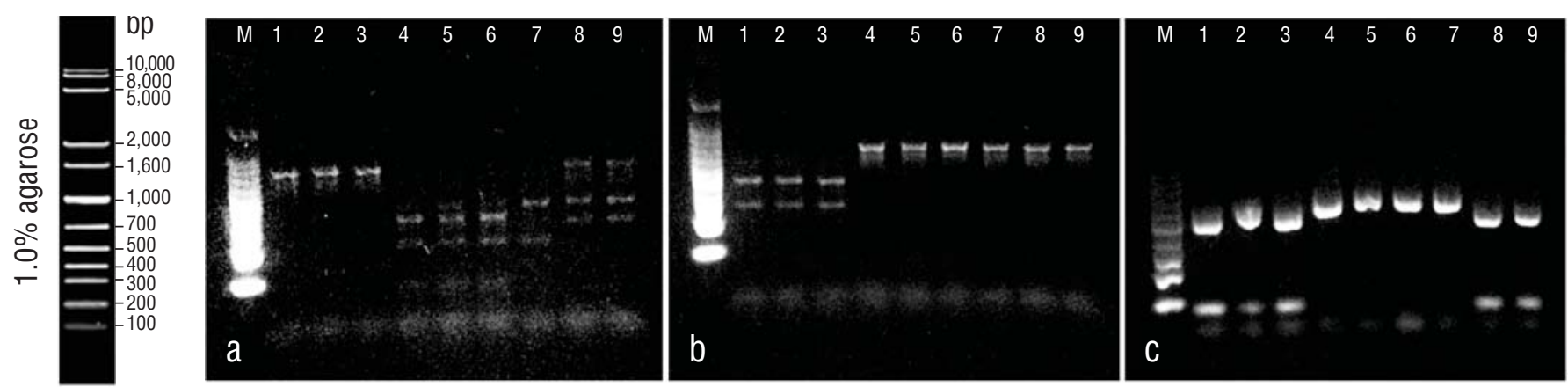

Figure 3. RFLP validation. Agarose gels (1\%) showing digestion results with HpaII (a), AvaII (b), and RsaI (c). In all gels, lanes 1-3 correspond to Opisthonema bulleri, 4-7 to Opisthonema medirastre, and 8-9 to Opisthonema libertate.

Figura 3. Validación de la RFLP. Geles de agarosa (1\%) que muestran los resultados de la digestión con HpaII (a), AvaII (b) y RsaI (c). En todos los geles, los carriles 1-3 corresponden a Opisthonema bulleri, 4-7 a Opisthonema medirastre y 8-9 a Opisthonema libertate.

for the absence of restriction sites (haplotype B), and for $O$. medirastre, characterized for the recognition of one restriction sites (haplotype $\mathrm{C}$ ). Considering these results, the HpaII enzyme allowed discrimination between the 3 species, the AvaII enzyme distinguished $O$. bulleri from the other 2 species, and the RsaI enzyme discriminated $O$. medirastre from the other 2 species only when haplotype $\mathrm{C}$ was present. The composed haplotypes obtained directly of the revision of the 43 sequences considering the 3 enzymes were $\mathrm{AAA}$ and $\mathrm{AAB}$ for $O$. libertate; $\mathrm{BAB}, \mathrm{BAC}$, and $\mathrm{CAB}$ for $O$. medirastre; and DBA for O. bulleri (Table 2).

\section{Discussion}

Pacific thread herring identification has been done using meristic, morphometric, and genetic criteria (Pérez-Quiñónez et al. 2017). The use of meristic and morphometric criteria requires that organisms be in good shape so that diagnostic characteristics can be observed clearly. Genetic analysis requires only a tissue sample to carry out successful identifications, but because molecular protocols are complex, the search for and design of strategies to simplify these protocols are important.

The PCR-RFLP technique applied in this study to Pacific thread herring identification was highly efficient, and we thus considered it relevant for supporting other identification procedures based on non-genetic variables (Berry and Barret 1963, Torres-Ramírez 2004, Pérez-Quiñónez et al. 2017). The 43 sequences that were reviewed to detect differences in restriction patterns revealed restriction sites that allow to discriminate the 3 species. Our analysis demonstrated that identification based on meristic and morphological characteristics can be biased, even if the person carrying out the identification is experienced in the use of specialized keys. In the present study, preliminary identification using the proposed keys for the Opisthonema genus resulted in erroneous results in some cases. After analyzing the restriction patterns and reviewing the sequences, individuals were correctly relocated (Fig. 4). para O. libertate, caracterizada por la ausencia de sitios de restricción (haplotipo B), y para O. medirastre, caracterizada por el reconocimiento de uno de los sitios de restricción (haplotipo C). Tomando en cuenta estos resultados, la enzima HpaII permitió la discriminación entre las 3 especies, la enzima AvalI distinguió O. bulleri de las otras 2 especies y la enzima RsaI discriminó O. medirastre de las otras 2 especies sólo cuando apareció el haplotipo C. Los haplotipos compuestos obtenidos directamente de la revisión de las 43 secuencias considerando las 3 enzimas fueron $\mathrm{AAA}$ y $\mathrm{AAB}$ para O. libertate; $\mathrm{BAB}, \mathrm{BAC}$ y $\mathrm{CAB}$ para $O$. medirastre; y DBA para O. bulleri (Tabla 2).

\section{Discusión}

La identificación de la sardina crinuda se ha basado en criterios merísticos, morfométricos y genéticos (PérezQuiñónez et al. 2017). El empleo de criterios merísticos y morfométricos requiere que los organismos se encuentren en buen estado para que se puedan observar las características diagnósticas claramente. El análisis genético sólo requiere una muestra de tejido para llevar a cabo identificaciones exitosas, pero debido a que los protocolos moleculares son complejos, es importante buscar y diseñar estrategias que permitan simplificarlos.

La técnica de PCR-RFLP aplicada en este estudio para la identificación de la sardina crinuda fue altamente eficiente $y$, por tanto, lo consideramos relevante como soporte para otros procedimientos de identificación basados en variables no genéticas (Berry y Barret 1963, Torres-Ramírez 2004, Pérez-Quiñónez et al. 2017). Las 43 secuencias que fueron revisadas para detectar diferencias en los patrones de restricción revelaron sitios de restricción que permiten discriminar a las 3 especies. El análisis demostró que la identificación basada en características merísticas y morfológicas puede estar sesgada, aun cuando la persona que realiza la identificación tenga experiencia en el uso de claves especializadas. En el presente estudio, la identificación preliminar mediante las claves propuestas para el género Opisthonema dio 
The PCR-RFLP technique was successful in discriminating adult Opisthonema species because, in large part, of the relatively simple procedure for amplifying the COI gene. Specific primers were designed in this study, resulting in the high success of the described protocol, as has also been reported in other studies (Vergara-Chen et al. 2009, Clusa et al. 2017, Guan et al. 2018, Pérez-Quiñonez et al. 2019). Compared with other PCR methods, the combination of specific primers and RFLP has advantages in terms of simplicity, specificity, and sensibility, and it has been used to identify food and species (Lin and Hwang 2007, GarcíaRodríguez et al. 2008, Vergara-Chen et al. 2009, Huang et al. 2013, Erwanto et al. 2014, Clusa et al. 2017). Thus, commercial samples with different degrees of processing can be analyzed, provided that the DNA has not been overly degraded (Lin and Hwang 2007).

PCR-RFLP can detect a large number of animal species and differentiate between animal species that are taxonomically close (Guan et al. 2018). Since the Opisthonema fishery focuses only on the capture of $O$. bulleri, O. medirastre, and $O$. libertate, there is no other Opisthonema species on the Pacific coast of Mexico, and the Opisthonema genus can be morphologically distinguished from other resultados erróneos en algunos casos. Después de analizar los patrones de restricción y revisar las secuencias, los individuos fueron reubicados correctamente (Fig. 4).

La técnica de PCR-RFLP tuvo éxito en la discriminación de organismos adultos de Opisthonema debido, en gran parte, al procedimiento relativamente simple para amplificar el gen COI. En este estudio se diseñaron iniciadores específicos, por lo cual el éxito del protocolo descrito fue alto, tal como ha sido reportado en otros estudios (Vergara-Chen et al. 2009, Clusa et al. 2017, Guan et al. 2018, Pérez-Quiñonez et al. 2019). En comparación con otros métodos de la PCR, la combinación de iniciadores específicos y el procedimiento de RFLP tiene ventajas en términos de simplicidad, especificidad y sensibilidad, y se ha utilizado para la identificación de alimentos y especies (Lin y Hwang 2007, García-Rodríguez et al. 2008, Vergara-Chen et al. 2009, Huang et al. 2013, Erwanto et al. 2014, Clusa et al. 2017). En consecuencia, se pueden analizar muestras comerciales con diversos grados de procesamiento, siempre que el ADN no haya sido muy degradado (Lin y Hwang 2007).

La PCR-RFLP puede detectar una gran cantidad de especies animales y diferenciar entre especies taxonómicamente cercanas (Guan et al. 2018). Debido a que la pesca

Table 2. COI gene (464 bp) fragment sizes of the 43 sequences obtained from the HpaII, RsaI, and AvaII restriction enzyme recognition sites for the 3 Opisthonema species. Hap = haplotypes, $\%=$ percentage of haplotype occurrence in all analyzed sequences. Haplotypes in bold and italicized font were found in the sequences that were downloaded from Genbank. The composite haplotypes were found in the revision of the 43 sequences considering the 3 enzymes.

Tabla 2. Tamaños de los fragmentos del gen COI (464 pb) de las 43 secuencias obtenidas de los sitios de reconocimiento de enzimas de restricción HpaII, RsaI y AvaII de las 3 especies de Opisthonema. Hap = haplotipos, \% = porcentaje de ocurrencia del haplotipo en el total de las secuencias analizadas. Los haplotipos en negritas y cursivas provinieron de las secuencias descargadas de Genbank. Los haplotipos compuestos se encontraron directamente de la revisión de las 43 secuencias considerando las 3 enzimas.

\begin{tabular}{|c|c|c|c|c|c|}
\hline Species & Enzyme & $\begin{array}{l}\text { Fragment size } \\
\text { (bp) }\end{array}$ & Hap & $\%$ & $\begin{array}{c}\text { Composite Hap } \\
(\%)\end{array}$ \\
\hline \multirow[t]{4}{*}{ Opisthonema libertate } & HpaII & 223,241 & A & 100 & AAA (94.0) \\
\hline & AvaII & 464 & A & 100 & $\mathrm{AAB}(6.0)$ \\
\hline & RsaI & 62,402 & A & 94 & \\
\hline & & 464 & B & 6 & \\
\hline \multirow[t]{5}{*}{ Opisthonema medirastre } & HpaII & $41,182,57,184$ & $\mathrm{~B}$ & 92 & BAB (75.0) \\
\hline & & $41,182,241$ & $\mathrm{C}$ & 8 & BAC (16.7) \\
\hline & AvaII & 464 & A & 100 & $\mathrm{CAB}(8.3)$ \\
\hline & RsaI & 464 & $\mathrm{~B}$ & 83 & \\
\hline & & 104,360 & $C$ & 17 & \\
\hline \multirow[t]{3}{*}{ Opisthonema bulleri } & HpaII & 464 & $\mathrm{D}$ & 100 & DBA (100) \\
\hline & AvaII & 210,254 & $\mathrm{~B}$ & 100 & \\
\hline & RsaI & 62,402 & $\mathrm{~A}$ & 100 & \\
\hline
\end{tabular}




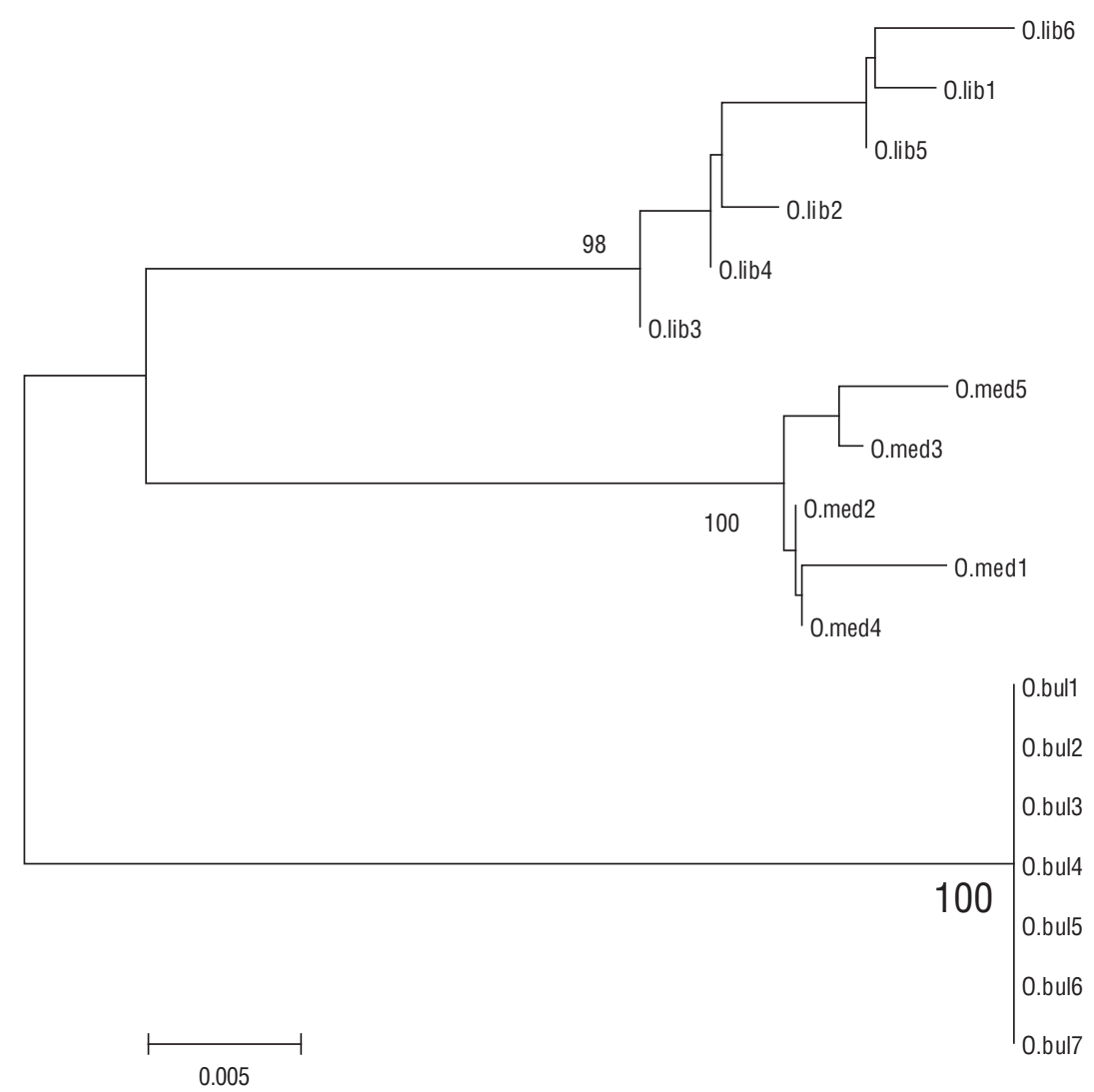

Figure 4. Neighbor-joining phylogenetic tree based on the mitochondrial COI gene haplotypes from a total of 18 adults of 3 Pacific thread herring species: Opisthonema libertate (O.lib), Opisthonema medirastre (O.med), and Opisthonema bulleri (O.bul). Tree reconstruction was based on Kimura's 2-parameter distance (K2P) model with 1,000 replications. Numbers on the nodes are bootstrap values. The branch length is measured as the number of nucleotide substitutions. O.lib1, O.med5, and O.bul1 represent the organisms that were correctly relocated using the PCR-RFLP technique.

Figura 4. Árbol filogenético del vecino más cercano basado en los haplotipos del gen mitocondrial COI de un total de 18 adultos de las 3 especies de sardina crinuda: Opisthonema libertate (O.lib), Opisthonema medirastre (O.med) y Opisthonema bulleri (O.bul). La reconstrucción de los árboles está basada en el modelo de Kimura de 2 parámetros (K2P) con 1,000 repeticiones. Los números en los nodos son valores de soporte de las ramas. La longitud de la rama se mide como el número de sustituciones de nucleótidos. O.lib1, O.med5 y O.bul1 representan los organismos que fueron reubicados correctamente utilizando la técnica PCR-RFLP.

genera, confusion of digestion profiles of other species is absent. However, the more complex use of PCR-RFLP could lie in the identification of incomplete organisms from a mixed sample. To explore this situation, we analyzed, in-silico, sequences available in Genbank for clupeids distributed in the region (Sardipos sagax: FJ165121-FJ165130, JF494407-JF494411; Etrumeus teres: MH378518, MH378548, MH378591, MH378495, HQ945957, JF493477-JF493481, JF952732, JF952733, GU440512; Dorosoma petenense: HQ573343-HQ573347; and Harengula thrissina: HQ010050), and we found that the digestion profiles were different among these species. Therefore, the set of enzymes that we have studied could (potentially) work for other commercially important species in the region that are phylogenetically close. A stronger effort should be done to explore the effectiveness of our primers and define in the best manner the digestion profiles for each species. de Opisthonema se centra solo en la captura de O. bulleri, $O$. medirastre y $O$. libertate, a que no se distribuye ninguna otra especie de Opisthonema en la costa mexicana del Pacífico y a que podemos diferenciar morfológicamente el género Opisthonema de otros géneros, la confusión con los perfiles de digestión de otras especies es ausente. Sin embargo, la utilidad más compleja de la PCR-RFLP podría estar en la identificación de organismos incompletos de una muestra mixta. Para explorar esta situación, analizamos, in-silico, secuencias disponibles en Genbank de clupeidos distribuidos en la región (Sardipos sagax: FJ165121-FJ165130, JF494407-JF494411; Etrumeus teres: MH378518, MH378548, MH378591, MH378495, HQ945957，JF493477-JF493481，JF952732，JF952733, GU440512; Dorosoma petenense: HQ573343-HQ573347; y Harengula thrissina: HQ010050) y encontramos perfiles de digestión diferentes entre estas especies. En consecuencia, el conjunto de enzimas que hemos estudiado podría 
The protocol developed in this study allowed the correct discrimination of the 3 Pacific thread herring species inhabiting the central and southern Gulf of California. It also allowed the simple detection of inexact species allocations based on morphological characteristics. In this sense, if there were any doubt in the identification of these 3 species regarding morphological or meristic characteristics, the PCR-RFLP of the COI gene protocol could be applied successfully. In case a new restriction pattern is found that leads to uncertainty, the analysis of the sequences could be considered as a last resort to support correct identifications and finds of new digestion profiles.

Adequate methods for the identification of species are chosen for different reasons, such as sensibility, specificity, precision, discrimination ability, reproducibility, cost, speed, equipment availability, and availability of duly trained personnel (Guan et al. 2018). We applied a protocol that consumes around $5 \mathrm{~h}$ (after DNA extraction), has a relatively low cost, and requires equipment that is found in any molecular ecology laboratory. The information provided in this study on the genetic identification of adults in the Opisthonema spp. Pacific thread herring complex constitutes a valuable tool because studies centered on the taxonomic or ecological revision or on the fishery resource management of this complex require precise identification of species.

\section{ACKNOWLedgments}

Financing for the collection of biological material was provided by the Secretaría de Investigación y Posgrado, Instituto Politécnico Nacional (IPN) (SIP: 20150882 and 20180539). This work was also supported by the Consejo Nacional de Ciencia y Tecnología (CONACYT, Mexico) (CB-2016-01-284944). CIPQ benefited from a graduate research scholarship granted by CONACYT and from the IPN Beca de Estímulo Institucional de Formación de Investigadores. CQV and FJGR are fellows of the Comisión de Operación y Fomento de Actividades Académicas-IPN, Estímulos al Desempeño de los Investigadores-IPN, and Sistema Nacional de Investigadores-CONACYT.

\section{REFERENCES}

Alacs EA, Georges A, FitzSimmons NN, Robertson J. 2009. DNA detective: a review of molecular approaches to wildlife forensics. Forensic Sci Med Pathol. 6(3):180-194. https://doi.org/10.1007/s12024-009-9131-7

Berry FH, Barrett I. 1963. Gillraker analysis and speciation in the thread herring genus Opisthonema = Análisis de las branquispinas y denominación de las especies del arenque de hebra Opisthonema. Bull Inter-Am Trop Tuna Comm. 7(2):137-190.

Clusa L, Ardura A, Fernández S, Roca AA, García-Vázquez E. 2017. An extremely sensitive nested PCR-RFLP mitochondrial marker for detection and identification of salmonids in eDNA from water samples. PeerJ. 5:e3045.

https://doi.org/10.7717/peerj.3045 (potencialmente) funcionar con otras especies comercialmente importantes en la región que son filogenéticamente cercanas. Se debe hacer un esfuerzo más fuerte para explorar la efectividad de nuestros iniciadores y definir de mejor manera los perfiles de digestión de cada especie.

El protocolo desarrollado en este estudio permitió la correcta discriminación de las 3 especies de sardina crinuda que habitan en el centro y sur del golfo de California. También permitió la detección sencilla de asignaciones inexactas de especies basadas en características morfológicas. En este sentido, si existieran dudas en la identificación de estas 3 especies con respecto a las características morfológicas o merísticas, el protocolo de la PCR-RFLP basado en el gen COI podría aplicarse con éxito. En caso de que se encuentre un nuevo patrón de restricción que conduzca a una incertidumbre, el análisis de las secuencias podría considerarse como un último recurso para respaldar las identificaciones correctas y los hallazgos de nuevos perfiles de digestión.

Los métodos adecuados para la identificación de especies se eligen por diferentes razones, como la sensibilidad, la especificidad, la precisión, la capacidad de discriminación, la reproducibilidad, el costo, la velocidad, la disponibilidad del equipo y la disponibilidad de personal debidamente capacitado (Guan et al. 2018). Nosotros aplicamos un protocolo que consume alrededor de $5 \mathrm{~h}$ (después de la extracción del ADN), tiene un costo relativamente bajo y requiere de equipo que se encuentra en cualquier laboratorio de ecología molecular. La información proporcionada en este estudio sobre la identificación genética de adultos en el complejo de sardina crinuda Opisthonema spp. constituye una herramienta valiosa debido a que los estudios centrados en revisiones taxonómicas o ecológicas o en el manejo de los recursos pesqueros de este complejo requieren la identificación precisa de las especies.

\section{Agradecimientos}

El financiamiento para la recolección de material biológico fue provisto por la Secretaría de Investigación y Posgrado, Instituto Politécnico Nacional (IPN) (SIP: 20150882 y 20180539). Además, este trabajo fue apoyado por el Consejo Nacional de Ciencia y Tecnología (CONACYT, México) (CB-2016-01-284944). CIPQ se benefició de una beca de investigación de posgrado otorgada por el CONACYT y de la Beca de Estímulo Institucional de Formación de Investigadores del IPN. CQV y FJGR son becarios de la Comisión de Operación y Fomento de Actividades Académicas-IPN, Estímulos al Desempeño de los Investigadores-IPN y Sistema Nacional de Investigadores-CONACYT. 
Erwanto Y, Abidin MZ, Sugiyono EYPM, Rohman A. 2014. Identification of pork contamination in meatballs of Indonesia local market using polymerase chain reaction-restriction fragment length polymorphism (PCR-RFLP) analysis. AsianAustralas J Anim Sci. 27(10):1487-1492. https://doi.org/10.5713/ajas.2014.14014

Fernández-Fernández S. 2018. ADN ambiental y sus aplicaciones en la evaluación de conectividad en ecosistemas acuáticos $=$ Environmental DNA and its applications to evaluate connectivity in aquatic ecosystems [dissertation]. [Asturias (Spain)]: Universidad de Oviedo. 235 p. http://hdl.handle.net/10651/50414.

Ferrito V, Raffa A, Rossitto L, Federico C, Saccone S, Pappalardo AM. 2019. Swordfish or shark slice? A rapid response by COIBar-RFLP. Foods. 8(11):537. https://doi.org/10.3390/foods8110537

García-Rodríguez FJ, Ponce-Díaz G, Muñoz-García I, GonzálezArmas R, Pérez-Enríquez R. 2008. Mitochondrial DNA markers to identify commercial spiny lobster species (Panulirus spp.) from the Pacific coast of Mexico: an application on phyllosoma larvae. Fish Bull. 106(2):204-212.

Guan F, Jin YT, Zhao J, Xu AC, Luo YY. 2018. A PCR method that can be further developed into PCR-RFLP assay for eight animal species identification. J Anal Methods Chem. 2018:5890140. https://doi.org/10.1155/2018/5890140

Huang X, Zhou X, Lin Q, Fang W, Chen X. 2013. PCR-RFLP technique for species identification of molted feathers in six species of co-occurring Ardeids. Conserv Genet Resour. 5(3):817-819. https://doi.org/10.1007/s12686-013-9916-6

Jacob-Cervantes M. 2010. Small pelagic fish fishery in the south of Gulf of California. Season 2008 analysis. Cien Pesq. 18:47-58.

Koressaar T, Remm M. 2007. Enhancements and modifications of primer design program Primer3. Bioinformatics. 23(10):1289-1291

Lampa S, Jean-Baptiste M, Gruber B, Klenke R, Henle K. 2015. Non-invasive genetic mark-recapture as a means to study population sizes and marking behaviour of the elusive Eurasian otter (Lutra lutra). PLOS ONE. 10(5):e0125684. https://doi.org/10.1371/journal.pone.0125684

Lin WF, Hwang DF. 2007. Application of PCR-RFLP analysis on species identification of canned tuna. Food Control. 18(9):1050-1057.

https://doi.org/10.1016/j.foodcont.2006.07.001
Pérez-Enríquez R, Díaz-Viloria N, Cruz-Hernández P, ArancetaGarza F, Gutiérrez-González JL, Arciniega-de los Santos A, Max-Aguilar A. 2016. Estudios de genética en poblaciones de abulón y sus aplicaciones en ordenamiento pesquero $=$ Genetic studies in abalone populations and their applications in fisheries management. Recursos Naturales y Sociedad. 2(2):24-39. https://doi.org/10.18846/renaysoc.2016.02.02.02.0002

Pérez-Quiñonez CI, Quiñonez-Velázquez C, García-Rodríguez FJ. 2019. Genetic homogeneity of the Pacific thread herring (Opisthonema libertate) (Günther, 1867) in the Eastern Pacific, inferred from mtDNA sequences. Mitochondrial DNA Part A. 30(3):517-524. https://doi.org/10.1080/24701394.2019.1570173

Pérez-Quiñónez CI, Quiñónez-Velázquez C, Ramírez-Pérez JS, Vergara-Solana FJ, García-Rodríguez FJ. 2017. Combining geometric morphometrics and genetic analysis to identify species of Opisthonema Gill, 1861 in the eastern Mexican Pacific. J Appl Ichthyol. 33(1):84-92. https://doi.org/10.1111/jai.13051

Tamura K, Stecher G, Peterson D, Filipski A, Kumar S. 2013. MEGA6: Molecular Evolutionary Genetics Analysis version 6.0. Mol Biol Evol. 30(12):2725-2729. https://doi.org/10.1093/molbev/mst197

Thompson JD, Gibson TJ, Plewniak F, Jeanmougin F, Higgins DG. 1997. The CLUSTAL_X Windows interface: Flexible strategies for multiple sequence alignment aided by quality analysis tools. Nucleic Acids Res. 25(24):4876-4882. https://doi.org/10.1093/nar/25.24.4876

Torres-Ramírez MN. 2004. New identification key for the 'thread herring' of the genus Opisthonema (Gill, 1861) in the Mexican Pacific [BSc thesis]. [Culiacan, Sinaloa (Mexico)]: Universidad Autónoma de Sinaloa.

Untergasser A, Cutcutache I, Koressaar T, Ye J, Faircloth BC, Remm M, Rozen SG. 2012. Primer3-new capabilities and interfaces. Nucleic Acids Res. 40(15):e115

Vergara-Chen C, González-Wangüemert M, Bermingham E, D'Croz L. 2009. Identification of weakfish Cynoscion (Gill) in the Bay of Panama with RFLP markers. J Fish Biol. 75(5):1101-1107.

https://doi.org/10.1111/j.1095-8649.2009.02356.x

Received October 2019,
accepted May 2020. 